\title{
Microbiological Characterization of the International Space Station Water Processor Assembly External Filter Assembly $\mathrm{S} / \mathrm{N} 01$
}

\author{
Natalee Weir ${ }^{1}$ \\ The Boeing Company, Huntsville, AL 35824 \\ Mark Wilson ${ }^{2}$ \\ The Boeing Company, Houston, TX 77059 \\ Airan Yoets, Thomas Molina, and Rebekah Bruce ${ }^{3}$ \\ Wyle Laboratories, Houston, TX 77058 \\ Glenn Sitler ${ }^{4}$ \\ Hamilton Sundstrand Space Systems International, Inc., Windsor Locks, CT, 06095 \\ and \\ Layne Carter ${ }^{5}$ \\ NASA Marshall Space Flight Center, Hunntsville, AL 35812
}

\begin{abstract}
The External Filter Assembly (EFA) S/N 01 is a mesh screen filter with a pore size of approximately $300 \mu \mathrm{m}$ that was installed in the International Space Station (ISS) Water Processor Assembly (WPA) between the Waste Tank and the Mostly Liquid Separator (MLS) on February 11, 2010 to protect clearances in the MLS solenoid valve SV_1121_3. A removal \& replacement of the EFA Filter was performed on March 22, 2011 in response to increasing pressure across the Waste Tank solenoid valve SV_1121_1 and the EFA Filter. The EFA Filter was returned on ULF6 and received in the Boeing Huntsville Laboratory on June 13, 2011. The filter was aseptically removed from the housing, and the residual water was collected for enumeration and identification of bacteria and fungi. Swab samples of the filter surface were also collected for microbiological enumeration and identification. Sample analyses were performed by Boeing Huntsville Laboratory and NASA Johnson Space Center Microbiology for comparison. Photographic documentation of the EFA filter was performed using a stereo microscope and environmental scanning electron microscope. This paper characterizes the amount and types of microorganisms on the filter surface and in the residual water from the filter housing following 1 year of utilization in the ISS WPA.
\end{abstract}

\section{Nomenclature}

$E F A=$ External Filter Assembly

ISS $\quad=$ International Space Station

$W P A \quad=$ Water Processor Assembly

${ }^{1}$ Lead Microbiologist, Boeing Research \& Technology, 499 Boeing Blvd., MC JW-56, Huntsville, AL 35824.

2 Associate Technical Fellow, Boeing Research \& Technology, 13100 Space Center Blvd., MC HB3-20, Houston, TX 77059, Senior Member.

${ }^{3}$ Insert Job Title, Department Name, Address/Mail Stop, and AIAA Member Grade for third author.

${ }^{4}$ Insert Job Title, Department Name, Address/Mail Stop, and AIAA Member Grade for fourth author.

${ }^{5}$ Insert Job Title, Department Name, Address/Mail Stop, and AIAA Member Grade for fifth author.

${ }^{6}$ Insert Job Title, Department Name, Address/Mail Stop, and AIAA Member Grade for sixth author.

${ }^{7}$ Life Support Development Team Lead, NASA MSFC ES62, Senior Member. 


$\begin{array}{ll}M L S & =\text { Mostly Liquid Separator } \\ M F & =\text { Multifiltration } \\ O R U & =\text { Orbital Replacement Unit } \\ N A S A & =\text { National Aeronautics and Space Administration } \\ J S C & =\text { Johnson Space Center } \\ k P a & =\text { Kilopascal } \\ c m & =\text { Centimeter } \\ m L & =\text { Milliliter } \\ C & =\text { Celsius } \\ M I S & =\text { Microbial Identification System } \\ S / N & =\text { Serial Number } \\ Q D & =\text { Quick Disconnect } \\ E S E M & =\text { Environmental Scanning Electron Microscope } \\ F T I R & =\text { Fourier Transform Infrared } \\ T & =\text { Transmittance } \\ C F U & =\text { Colony Forming Units }\end{array}$

\section{Introduction}

$\mathrm{T}$ HE International Space Station (ISS) Water Processor Assembly (WPA) produces potable water from a combination of humidity condensate and urine distillate provided from the Urine Processor Assembly. The WPA consists of a waste water tank (bellows maintains approximately $5.2-15.5 \mathrm{kPa}$ ), the mostly liquid separator (MLS) for gas removal, separator filter for removal of odor-causing contaminants from entrained air, solenoid valves, pump, particulate filter, multifiltration (MF) beds for removal of inorganic and non-volatile organic contaminants from the water, sensor (to measure conductivity between the 2 MF Beds), a catalytic reactor for oxidation of polar organic contaminants, a regenerative heat exchanger to recover heat from the catalytic reactor, a gas separator to remove excess oxygen and gaseous oxidation by-products from process water, and a reactor health sensor to measure conductivity of the catalytic reactor effluent. ${ }^{1}$ An ion exchange bed removes dissolved oxidation products and adds iodine for residual microbiological control. ${ }^{1}$ The potable water is stored in the product water tank prior to delivery to the ISS potable water bus which has a small accumulator tank and a pump to deliver water on demand to users. ${ }^{1}$

The WPA began exhibiting an increased pressure drop between the waste tank and the MLS in June 2009. ${ }^{1}$ The WPA was operated at a reduced flow rate to allow more time for the waste tank to fill the MLS. The Pump/Sep Orbital Replacement Unit (ORU) which contains the MLS, solenoid valves, and the pump was replaced with a spare unit (S/N 02) in January 2010. ${ }^{1}$ Then on February 11, 2010, a $300 \mu \mathrm{m}$ mesh screen filter in the External Filter Assembly (EFA) was installed between the waste tank and MLS to help prevent obstruction of tight clearances in the Pump/Sep ORU. ${ }^{1}$ Nominal operation of the WPA was resumed after the EFA installation, and the failed Pump/Sep ORU was returned to the ground for a failure investigation which was performed at Hamilton Sundstrand the week of February 22, 2010. The MLS inlet solenoid valve SV_1121_3 was found to be occluded with a mixture of fungal and bacterial biomass. The biomass had accumulated in the valve between the poppet and the valve seat and obstructed the valve clearance in this region. ${ }^{1}$

After approximately one year of WPA operation with the EFA Filter installed, pressure increased across the Waste Tank solenoid valve SV_1121_1 and the EFA Filter. The EFA Filter was replaced with a spare on March 22, 2011 and returned to ground on ULF6. The EFA Filter was received in the Boeing Huntsville Laboratory on June 13, 2011 for characterization of the biomass and other contaminants on the filter.

\section{Materials and Methods}

The EFA Filter was received in the Boeing Huntsville Laboratory on June 13, 2011. The EFA Filter contained in the outer shipping bags was placed under a Class II Laminar Flow Biosafety Cabinet for aseptic disassembly. The EFA Filter was removed from the shipping bag and weighed. The mesh filter was removed from the housing and the fluid was collected in a sterile container and the volume was determined. Surface samples of two $1 \mathrm{~cm}^{2}$ areas of the mesh screen filter were collected with sterile swabs wetted with neutralizing buffer. A surface sample of the inside of the filter housing was also collected by swabbing the circumference of the inner housing with a sterile swab wetted with neutralizing buffer. The swabs were placed into tubes containing $5 \mathrm{~mL}$ of sterile neutralizing buffer. And a dry sterile cotton swab was used to collect material on the mesh screen for Fourier Transform Infrared microscopy and placed into a sterile tube. Photographs were taken of all phases of the engineering evaluation of the 
EFA Filter. Stereomicroscopic and environmental scanning electron micrographs were also taken of the mesh screen filter. The mesh screen filter was aseptically cut from the end caps and a longitudinal cut was made to open the circular mesh screen filter in order to view the outlet (inside) of the filter.

The Boeing Huntsville Laboratory performed heterotrophic bacteria and fungi enumerations and identifications on a portion of the fluid sample and wet swab samples collected from the mesh screen and inside of the EFA filter housing. Microorganisms on the swabs were dispersed into the neutralizing buffer by three repetitions of vortexing for 30 seconds followed by sonication for one minute. Enumerations on the fluid sample and neutralizing buffer from the swabs were performed by membrane filtration. ${ }^{2}$ Membrane filters for bacteria were placed on R2A agar, and then incubated for 7 days at $28^{\circ} \mathrm{C}$. The membrane filters for fungi were placed on modified Emmon's Agar, which contains chloramphenicol and rose bengal to inhibit bacterial growth, and then incubated for 5 days at $25^{\circ} \mathrm{C}$. Counts of bacteria and fungi were reported as colony forming units (CFU)/mL for fluid or CFU $/ \mathrm{cm}^{2}$ for the swabs. Bacteria identifications were performed using the Sherlock ${ }^{\circledR}$ Microbial Identification System (MIS) which is based on cellular fatty acid analysis by gas chromatography. Bacteria identifications were also performed using the Biolog MicroLog Identification System that is based on carbon source utilization patterns within a 96 well microplate using oxidation-reduction chemistry. Fungal identifications were done by classical morphological and microscopic examination.

The remaining fluid from the EFA housing and a set swab sample of the mesh screen were sent to the NASA JSC Microbiology for comparative analyses for bacteria and fungi. For bacterial analysis, samples were plated onto $\mathrm{R} 2 \mathrm{~A}$ and incubated at $35^{\circ} \mathrm{C}$ for 48 hours. Bacterial identifications were performed using standard biochemical and genetic analyses. Samples for fungal analysis were plated onto Sabouraud dextrose with chloramphenicol, potato dextrose agar, and malt extract and then incubated at $30^{\circ} \mathrm{C}$ for 5 days. Fungal identifications were done by classical morphological and microscopic examination.

\section{Results}

The EFA SV1018042-1 was received in good condition. There was no leaked fluid in the outer or inner shipping bags.

\section{A. Photographs of EFA Filter}

Figure 1 indicates the EFA with quick disconnects (QDs) attached as received in the laboratory prior to disassembly. After removal of the outlet QD, $3 \mathrm{~mL}$ of fluid from the filter and housing was collected into a sterile container. Figure 2 shows the mesh screen filter after removal from the housing.

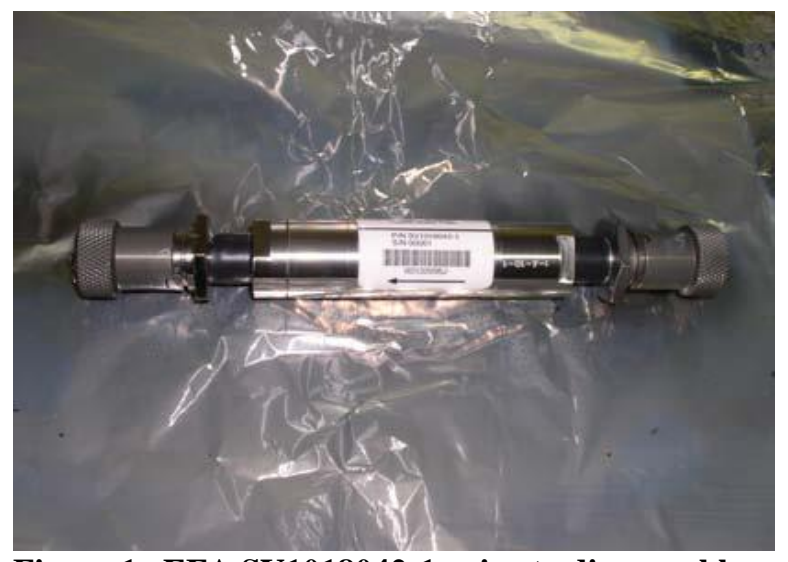

Figure 1. EFA SV1018042-1 prior to disassembly.

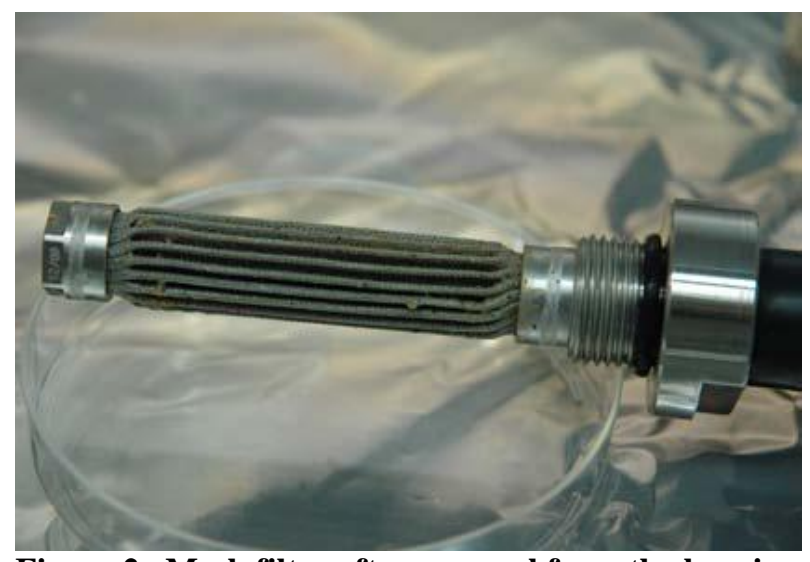

Figure 2. Mesh filter after removal from the housing.

\section{B. Stereomicroscope Photographs of Filter Inlet}

Swab samples were collected from the mesh screen filter and the filter was photographed using a stereomicroscope at approximately $35-50 x$ magnification. The stereomicroscopic images of the mesh filter in Figure 3 and Figure 4 indicate an almost total occlusion of the pores in the filter by a gelatinous biofilm. 


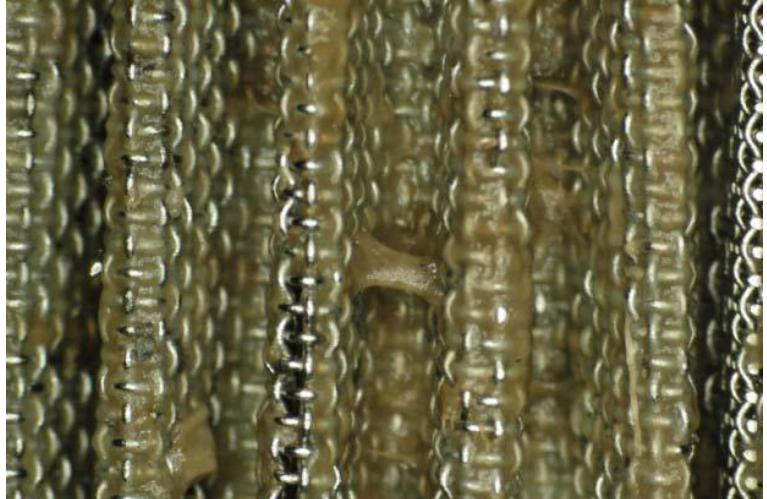

Figure 3. Filter inlet at $\approx 35 x$ Magnification.

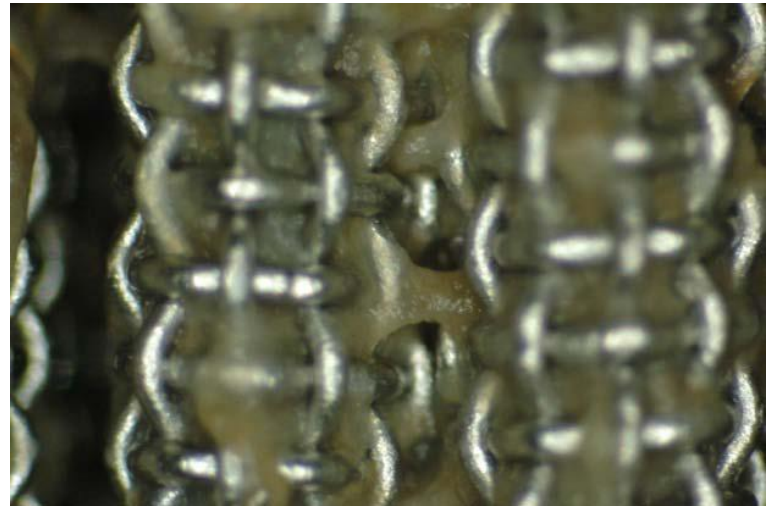

Figure 4. Filter inlet at $\approx 50 x$ Magnification.

\section{Environmental Scanning Electron Microscope Images of Filter Inlet}

The filter was placed into an environmental scanning electron microscope (ESEM) to get detailed images of the biofiolm structure prior to destructive analysis of the filter. Figure 5 is an ESEM photograph at 50x magnification. At this point, the biofiom had begun to dry after removal from the housing. Figure 6 shows a higher magnification (726x) ESEM photograph.

\section{EFA Filter After Sectioning}

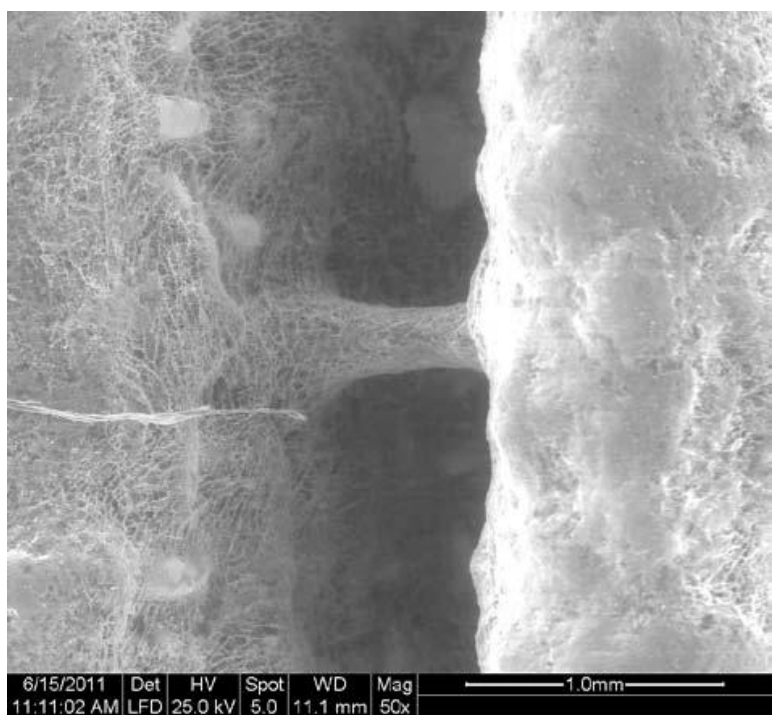

Figure 5. ESEM of filter at 50x magnification.

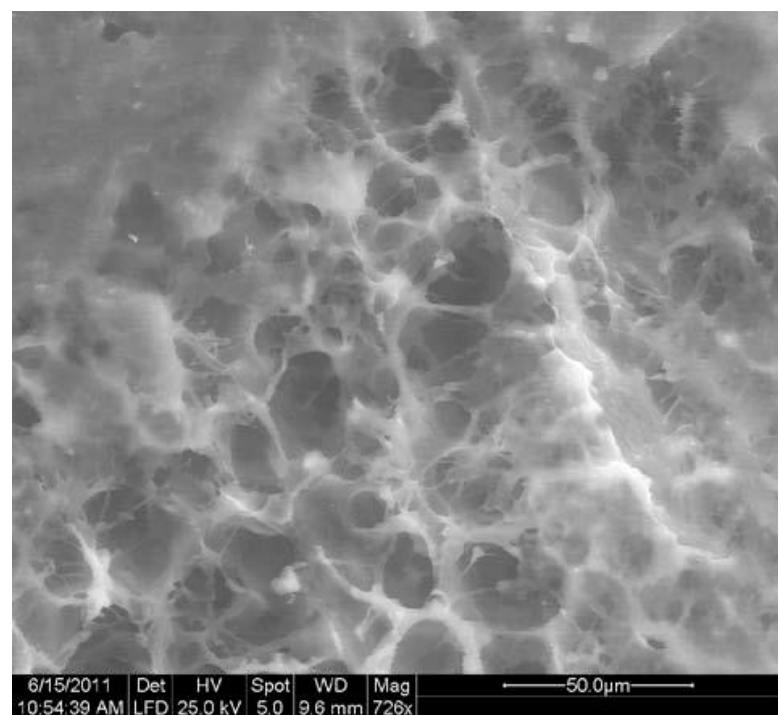

Figure 6. ESEM of filter at 726x magnification.

The mesh filter was destructively removed from the end caps, and a longitudinal cut of the filter was made to evaluate the filter outlet (inside of the mesh screen). The cut filter is shown in Figure 7. Figure 8 is a stereomicroscope photograph of the filter outlet. Biofilm can be see extruding through the pores of the mesh filter. 


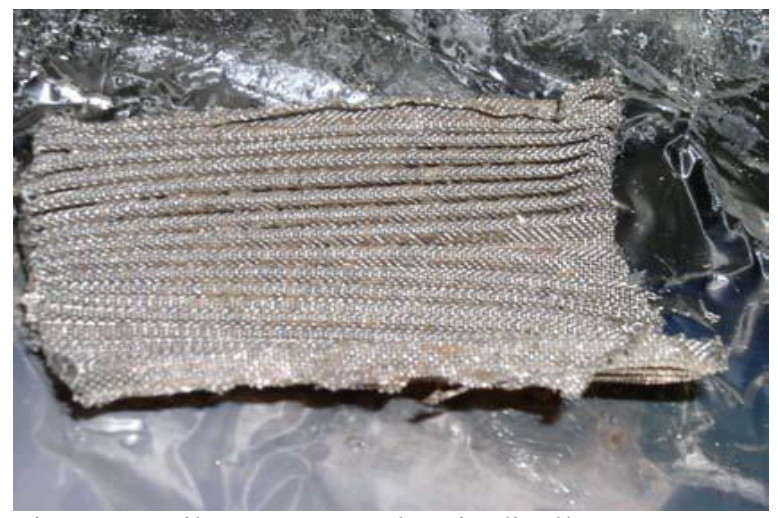

Figure 7. Filter screen cut longitudinally.

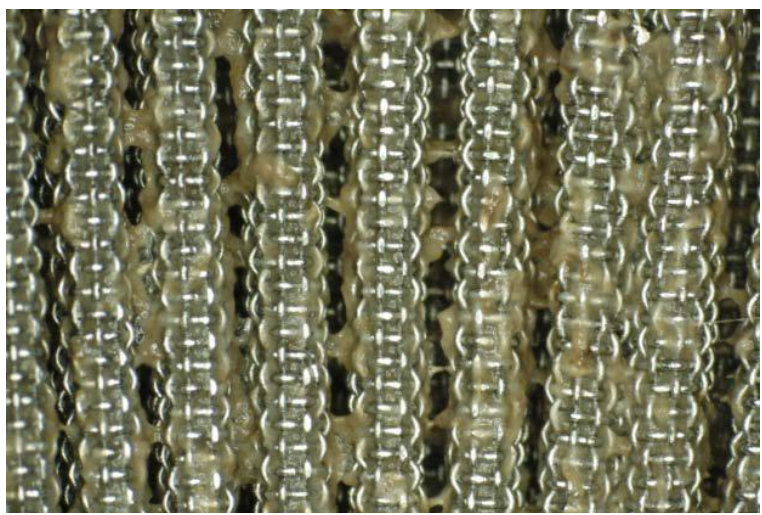

Figure 8. Stereomicroscope image of filter outlet.

\section{E. Fouier Transform Infrared Spectroscopy}

Dry sterile swabs were used to collect biofilm from the filter inlet at three different locations for FTIR spectroscopy. The results are shown in Figure 9. The spectral characteristics are very similar for each spectrum. The amide deformation bands at $1650 \mathrm{~cm}^{-1}$ and $1550 \mathrm{~cm}^{-1}$ are characteristic of proteins. A more significant characteristic is the carbonyl bands around $1740-1720 \mathrm{~cm}^{-1}$, which have been associated with fungal biofilm.

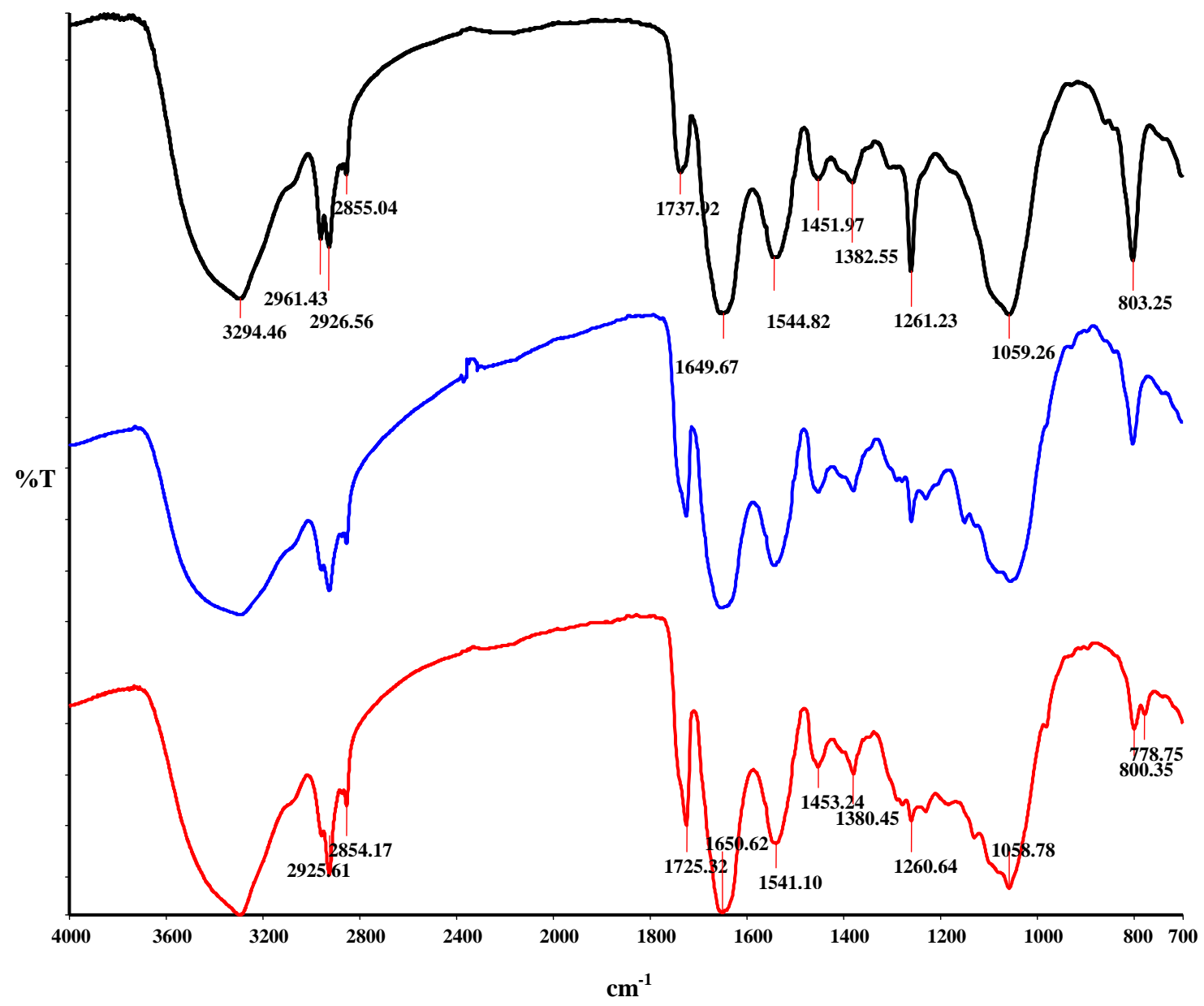

Figure 9. FTIR spectra of biofilm removed from filter inlet at 3 locations. 


\section{F. Boeing Huntsville Laboratory Microbiological Enumerations and Identifications}

The enumeration and identification of heterotrophic bacteria and fungi in fluid and suface swabs that were performed by Boeing Huntsville Laboratory are shown in Table 1. The relative species counts based on the totals for of each specific colony morphology on countable plates are provided following the species identification.

\begin{tabular}{|c|c|c|c|c|}
\hline $\begin{array}{c}\text { Sample } \\
\text { Description }\end{array}$ & $\begin{array}{c}\text { Bacteria } \\
\text { Count }\end{array}$ & $\begin{array}{c}\text { Bacteria } \\
\text { Identifications }\end{array}$ & $\begin{array}{l}\text { Fungi } \\
\text { Count }\end{array}$ & $\begin{array}{c}\text { Fungi } \\
\text { Identifications }\end{array}$ \\
\hline \multirow[t]{4}{*}{$\begin{array}{l}\text { Fluid from filter } \\
\text { housing }\end{array}$} & $\begin{array}{l}4.5 \mathrm{E}+03 \\
\mathrm{CFU} / \mathrm{mL}\end{array}$ & $\begin{array}{l}\text { Microbacterium laevaniformans - } \\
1.3 \mathrm{E}+03 \mathrm{CFU} / \mathrm{mL}\end{array}$ & $\begin{array}{l}2.1 \mathrm{E}+03 \\
\mathrm{CFU} / \mathrm{mL}\end{array}$ & $\begin{array}{l}\text { Lecythophora mutabilis - } \\
1.8 \mathrm{E}+03 \mathrm{CFU} / \mathrm{mL}\end{array}$ \\
\hline & & $\begin{array}{l}\text { Cupriavidus metallidurans - } \\
1.2 \mathrm{E}+03 \mathrm{CFU} / \mathrm{mL}\end{array}$ & & $\begin{array}{l}\text { Lecythophora hoffmannii- } \\
\text { 3.0E }+02 \text { CFU } / \mathrm{mL}\end{array}$ \\
\hline & & $\begin{array}{l}\text { Ralstonia pickettii - } \\
1.0 \mathrm{E}+03 \mathrm{CFU} / \mathrm{mL}\end{array}$ & & \\
\hline & & $\begin{array}{l}\text { Ralstonia paucula- } \\
1.0 \mathrm{E}+03 \mathrm{CFU} / \mathrm{mL}\end{array}$ & & \\
\hline \multirow[t]{4}{*}{$\begin{array}{l}\text { Swab from mesh } \\
\text { filter inlet }\end{array}$} & $\begin{array}{l}1.25 \mathrm{E}+02 \\
\mathrm{CFU} / \mathrm{cm}^{2}\end{array}$ & $\begin{array}{l}\text { Ralstonia pickettii- } \\
6.0 \mathrm{E}+03 \mathrm{CFU} / \mathrm{cm}^{2}\end{array}$ & $\begin{array}{l}1.9 \mathrm{E}+04 \\
\mathrm{CFU} / \mathrm{cm}^{2}\end{array}$ & $\begin{array}{l}\text { Lecythophora mutabilis - } \\
1.7 \mathrm{E}+04 \mathrm{CFU} / \mathrm{cm}^{2}\end{array}$ \\
\hline & & $\begin{array}{l}\text { Ralstonia paucula-- } \\
2.5 \mathrm{E}+03 \mathrm{CFU} / \mathrm{cm}^{2}\end{array}$ & & $\begin{array}{l}\text { Lecythophora hoffmannii- } \\
2.0 \mathrm{E}+03 \mathrm{CFU} / \mathrm{cm}^{2}\end{array}$ \\
\hline & & $\begin{array}{l}\text { Cupriavidus metallidurans - } \\
2.5 \mathrm{E}+03 \mathrm{CFU} / \mathrm{cm}^{2}\end{array}$ & & \\
\hline & & $\begin{array}{l}\text { Microbacterium laevaniformans - } \\
1.5 \mathrm{E}+03 \mathrm{CFU} / \mathrm{cm}^{2}\end{array}$ & & \\
\hline \multirow[t]{4}{*}{$\begin{array}{l}\text { Swab from inside } \\
\text { housing }\end{array}$} & $\begin{array}{l}1.77 \mathrm{E}+03 \\
\mathrm{CFU} / \mathrm{cm}^{2} \\
\end{array}$ & $\begin{array}{l}\text { Ralstonia paucula- } \\
1.02 \mathrm{E}+03 \mathrm{CFU} / \mathrm{cm}^{2}\end{array}$ & $\begin{array}{l}3.36 \mathrm{E}+03 \\
\mathrm{CFU} / \mathrm{cm}^{2}\end{array}$ & $\begin{array}{l}\text { Lecythophora hoffmannii- } \\
2.83 \mathrm{E}+03 \mathrm{CFU} / \mathrm{cm}^{2}\end{array}$ \\
\hline & & $\begin{array}{l}\text { Ralstonia pickettii- } \\
2.8 \mathrm{E}+02 \mathrm{CFU} / \mathrm{cm}^{2}\end{array}$ & & $\begin{array}{l}\text { Lecythophora mutabilis - } \\
5.3 \mathrm{E}+02 \mathrm{CFU} / \mathrm{cm}^{2}\end{array}$ \\
\hline & & $\begin{array}{l}\text { Comamonas testosteroni - } \\
2.8 \mathrm{E}+02 \mathrm{CFU} / \mathrm{cm}^{2}\end{array}$ & & \\
\hline & & $\begin{array}{l}\text { Cupriavidus metallidurans - } \\
1.9 \mathrm{E}+02 \mathrm{CFU} / \mathrm{cm}^{2}\end{array}$ & & \\
\hline
\end{tabular}

Table 1. Boeing Huntsville Laboratory enumeration and identification of bacteria and fungi.

\section{G. Fungal Cellular and Colony Morphology}

Figure 10 is a photograph of the colony morphology of a Lecythophora mutabilis isolate growing on potato dextrose agar. Initially, the colony has an orange pigment at the outer smooth edge with a fluffy grey center. As the culture matures, the center begins to darken to a yellowish-brown color. The cellular morphology of the Lecythophora mutabilis isolate is shown in Figure 11 using a lactophenol cotton blue stain. Phialides (bottle shaped basipetal cells) that produce conidia are present as well as pigmented, rounded, thick-walled cells known as chlamydospores. 


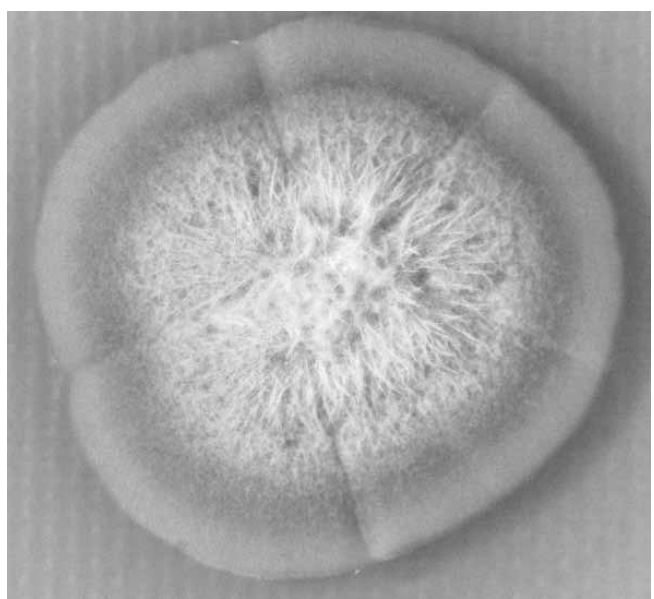

Figure 10. Lecythophora mutabilis colony morphology on potato dextrose agar.

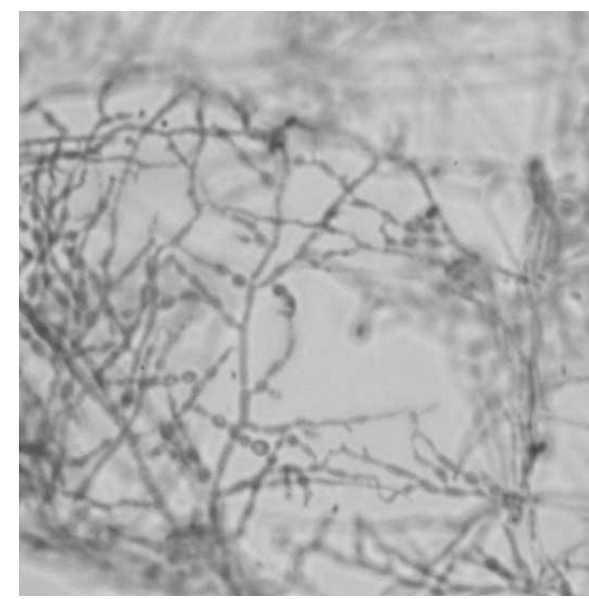

Figure 11. Lecythophora mutabilis cellular morphology stained with lactophenol cotton blue.

Figure 12 is a photograph of the colony morphology of a Lecythophora hoffmannii isolate growing on potato dextrose agar. The colony initially has a light pink color and a slimy texture with a downy center. The cellular morphology of the Lecythophora hoffmannii isolate is shown in Figure 13 using a lactophenol cotton blue stain. Adelophialides (not septate at the base) are interclalated in the hyphae and chlamydospores are not present.

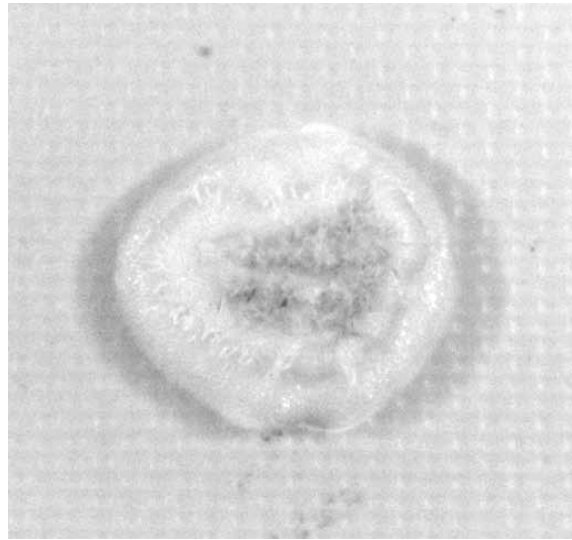

Figure 12. Lecythophora hoffmannii colony morphology on potato dextrose agar.

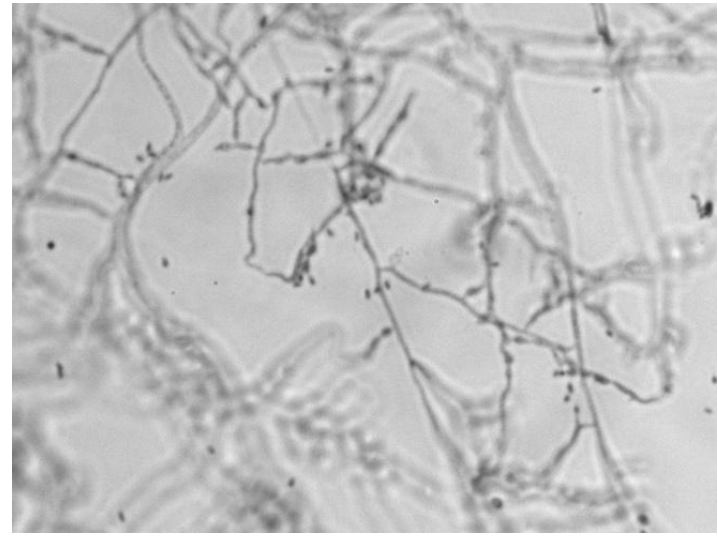

Figure 12. Lecythophora hoffmannii cellular morphology stained with Lactophenol cotton blue.

\section{H. NASA JSC Microbiological Enumerations and Identifications}

The enumeration and identification of heterotrophic bacteria and fungi in fluid and surface swabs that was performed by the NASA JSC Microbiology Laboratory is provided in Table 2.

\begin{tabular}{|l|l|l|l|l|}
\hline \multicolumn{1}{|c|}{$\begin{array}{c}\text { Sample } \\
\text { Description }\end{array}$} & Bacteria & \multicolumn{1}{|c|}{$\begin{array}{c}\text { Bacteria } \\
\text { Identifications }\end{array}$} & \multicolumn{1}{c|}{ Fungi } & \multicolumn{1}{c|}{$\begin{array}{c}\text { Fungi } \\
\text { Identifications }\end{array}$} \\
\hline $\begin{array}{l}\text { Fluid from filter } \\
\text { housing }\end{array}$ & $\begin{array}{l}1.4 \mathrm{E}+06 \\
\text { CFU/mL }\end{array}$ & Cellulomonas fimi & $\begin{array}{l}2.0 \mathrm{E}+03 \\
\text { CFU/mL }\end{array}$ & Aureobasidium pullulans \\
\hline $\begin{array}{l}\text { Swab from mesh filter } \\
\text { inlet }\end{array}$ & $\begin{array}{l}1.5 \mathrm{E}+02 \\
\text { CFU/cm }\end{array}$ & $\begin{array}{l}\text { Cupriavidus basilensis } \\
\text { CFU } / \mathrm{cm}^{2}\end{array}$ & Aureobasidium pullulans \\
\hline & & Microbacterium laevaniformans & & \\
\hline & & Cupriavidus metallidurans & & \\
\hline & & Burkholderia multivorans & & \\
\hline
\end{tabular}

Table 2. NASA JSC Microbiology Laboratory enumeration and identification of bacteria and fungi. 


\section{Discussion}

The EFA filter was preventing large mycelial fragments consisting of fungal hyphae, conidia, and chlamydospores greater than $300 \mu \mathrm{m}$ that could slough off the bellows in the WPA waste tank from impacting WPA ORUs. Smaller mycelial fragments, hyphae, conidia, chlamydospores, and bacteria could still pass through the EFA filter and attach as biofilm in tubing, manifolds, solenoid valves, and other hardware because there are plenty of nutrients in the wastewater to support bacterial and fungal growth. Over the approximately one year of WPA operation with the EFA filter installed, the filter became almost totally occluded with biofilm due to continued collection of bacteria and fungi on the filter and in situ growth of fungi on the filter. A major consequence of filter biofouling is penetration of filter material by the microorganisms and "grow through". ${ }^{3}$ The penetration can occur during dynamic and quiescent flow conditions. At the time of the EFA removal, the filter was contributing more bacterial and fungal contamination downstream than it was preventing.

The bacteria found in the water and surface samples on the EFA filter and housing are a mixture of Gram negative and Gram positive species commonly found in wastewater and soil. Several species of rod-shaped, motile, Gram negative, aerobic, and non-fermentative bacteria were present including Ralstonia pickettii, Ralstonia paucula, Cupriavidus metallidurans, Cupriavidus basilensis, Comamonas testosteroni, and Burkholderia multivorans. Ralstonia species are commonly found in biofilms in water systems and can cause nosocomial infections in immune compromised individuals. ${ }^{4}$ Cupriavidus metallidurans has the ability to survive in millimolar concentrations of heavy metals. ${ }^{5}$ Comamonas testosteroni can accumulate poly- $\beta$-hydroxybutyrate in the cell. ${ }^{6}$ Burkholderia multivorans has been known to colonize the lungs of cyctic fibrosis patients. ${ }^{7}$

Microbacterium laevaniformans is a motile Gram positive bacterium with irregular short rods ranging from 0.2 - 0.3 by $0.6-2.0 \mu \mathrm{m}^{8}{ }^{8}$ Cells were shorter in older cultures. Microbacterium laevaniformans is chemoorganotrophic and has primarily an aerobic respiratory metabolism with weakly fermentative with the production of acid from glucose and a few other carbohydrates. Although this same isolate was identified by cellular fatty acid analysis as Microbacterium chocolatum, additional testing including genetic analyses and growth in $5 \% \mathrm{NaCl}$ proved that the culture was actually Microbacterium laevaniformans. ${ }^{8}$ Cellulomonas fimi is a motile, Gram positive bacterium with slender, irregular rods from 0.5-0.6 by 2.0-5.0 $\mu \mathrm{m} .{ }^{9}$ Cellulomonas is a facultative anaerobe with respiratory and fermentative metabolism. ${ }^{9}$ It is commonly found in soil and decaying matter.

Species of the filamentous fungus Lecythophora were originally classified as members of the genus Phialophora due to the production of phialides. ${ }^{10}$ Lecythophora is commonly found in soil and decaying plant material. Rarely it is a human pathogen and can cause keratitis, enophthalmitis, peritonitis, and endocarditis. ${ }^{10}$ Aureobasidium pullulans is commonly found in humid indoor environments and is a contaminant of human skin, nails, and hair. ${ }^{10}$ Aureobasidium forms mucoid colonies that darken with age due to the appearance of brown hyphae that differentiate to chlamydospores at maturity. ${ }^{11}$ Hyaline blastoconidia are also produced. ${ }^{11}$

There were differences in bacteria and fungal counts and species reported by the Boeing Huntsville Laboratory and NASA JSC Microbiology Laboratory. Those differences may be due to the higher incubation temperatures $\left(35^{\circ} \mathrm{C}\right.$ versus $28^{\circ} \mathrm{C}$ for bacteria and $30^{\circ} \mathrm{C}$ versus $28^{\circ} \mathrm{C}$ for fungi) and shorter incubation times for bacteria (2 days versus 7 days). Different incubation temperatures could promote the growth of certain species and inhibit the growth of other species. Also, some slower growing environmental bacteria may not show up until after 48 hours of incubation. The highest bacteria count was reported by NASA JSC Microbiology in the fluid sample with Cellulomonas fimi at $1.4 \mathrm{E}+06 \mathrm{CFU} / \mathrm{mL}$. This bacterium could have overgrown other species during the time required to ship the samples to Houston, or it could also be a sampling contaminant.

\section{Conclusion}

The EFA filter prevented fungal mycelial mats greater than $300 \mu \mathrm{m}$ that may slough off the bellows in the waste tank from impacting downstream ORUs such as the Pump/Sep ORU with low flow regions in solenoid valves during one year of installation in the ISS WPA. Even before delta pressure began to increase across the EFA filter, the filter had become a source of more bacterial and fungal contamination downstream than it was preventing due to penetration and extrusion of biofilm through the filter. The data warrants a more frequent removal and replacement of the EFA filter. A more frequent recommended EFA filter replacement schedule of every $3-6$ months is unrealistic due to limitations on logistics and available crew time. Therefore, changes in operation of the WPA, which include an iodinated water flush of the solenoid valve at the end of a process cycle, are being considered to reduce the risk of biofouling in downstream ORUs. 


\section{Acknowledgments}

The work described in this paper was performed by NASA, Boeing, and Hamilton Sundstrand Space Systems International, Inc. under the auspices of the International Space Station contract, NAS15-10000. The authors wish to express their sincere thanks to Harold Cole, retired Boeing Associate Technical Fellow, for assistance in the engineering evaluation and Sam Manuel of Boeing for the FTIR spectroscopy.

\section{References}

${ }^{1}$ Carter, L., "Status of the Regenerative ECLS Water Recovery System," AIAA 2010-6216, presented at the 40 ${ }^{\text {th }}$ International Conference on Environmental Systems, Barcelona, Spain, July, 2010.

${ }^{2}$ Standard Methods for the Examination of Water and Wastewater $17^{\text {th }}$ ed., edited by L. S. Clesceri, A. E. Greenberg, and R. R. Trussell, American Public Health Association, Washington, DC, 1989.

${ }^{3}$ Mittelman M.W., "Biofilm Development in Purified Water Systems,", Microbial Biofilms edited by H. L. Lappin-Scott and J. W. Costerton, Cambridge Univ. Press, London, 1995, pp. 133-147.

${ }^{4}$ Vandamme, P., Goris, J., Coenye, T., Hoste, B., Janssens, D., Kersters, K., De Vos, P., and Falsen, E., "Assignment of Centers for Disease Control group IVc-2 to the Genus Ralstonia as Ralstonia paucula sp. nov.," Int. J. Syst. Bacteriol., Vol. 49, 1999, pp. 663-669.

${ }^{5}$ Vaneechoutte, M., Kämpfer, P., De Baere, T., Falsen, E., and Verschraegen, G.,"Wautersia gen. nov., a Novel Genus Accomodating the Phylogenetic Lineage Including Ralstonia eutropha and Related Species, and Proposal of Ralstonia [Pseudomonas] syzygii (Roberts et al. 1990) comb. nov.," Int. J. Syst. Evol. Microbiol., Vol. 54, 2004, pp. 317-327.

${ }^{6}$ Bergey's Manual of Determinative Bacteriology Ninth Ed., edited by J. G. Holt, N. R. Krieg, P. H. A. Sneath, J. T. Staley, and S. T. Williams, Williams \& Wilkins, Baltimore, 1994, p. 80.

${ }^{7}$ Jones, A. M., Dodd, M. E., Govan, J. R. W., Barcus, V., Doherty, C. J., Morris, J., and Webb, A. K. “Burkholderia cenocepacia and Burkholderia multivorans: Influence on Survival in Cystic Fibrosis," Thorax, Vol. 59, 2004, pp. 948-951.

${ }^{8}$ Takeuchi, M. and Hatano, K. "Proposal of Six New Species in the Genus Microbacterium and transfer of Flavobacterium marinotypicum ZoBell and Upham to the Genus Microbacterium as Microbacterium maritypicum comb. nov.," Int. J. Syst. Bacteriol. Vol. 48, 1998, pp. 973-982.

${ }^{9}$ Bergey's Manual of Determinative Bacteriology Ninth Ed., edited by J. G. Holt, N. R. Krieg, P. H. A. Sneath, J. T. Staley, and S. T. Williams, Williams \& Wilkins, Baltimore, 1994, p. 575.

${ }^{10}$ Identifying Fungi A Clinical Laboratory Handbook Second Ed., edited by G. St-Germain and R. Summerbell, Star Publishing Company, Inc., Belmont, CA, 2011, pp. 164-165.

${ }^{11}$ Identifying Fungi A Clinical Laboratory Handbook Second Ed., edited by G. St-Germain and R. Summerbell, Star Publishing Company, Inc., Belmont, CA, 2011, pp. 76-77. 